\title{
SHINKO ZAIBATSU
}

(The New Zaibatsu)

By Masaru Udagawa, Nihon Keizai Shinbunsha, 1984, $288+$ xxii pages.

By Takeshi Oshio

Meiji Gakuin University

In discussing the Japanese economy prior to World War II, one cannot ignore the enterprise groups known as zaibatsu, the giant business combines of prewar Japan. In the 1930s the so-called "new zaibatsu" emerged as rivals to the old combines represented by Mitsui, Mitsubishi, and Sumitomo. Research on these new zaibatsu has recently undergone remarkable progress. Among those responsible for this trend is Masaru Udagawa, who has made a major contribution to the field through his work on one of the new zaibatsu, Nissan. Having diligently followed the studies that have been done so far on other new zaibatsu, Udagawa has attempted in this book to paint an overall picture of these enterprise groups. This represents a long-awaited work, written by the person most qualified for the job.

In Part I, entitled "The Business History of the New Zaibatsu," Udagawa traces the development of five new zaibatsu: Nissan, built up through a conglomerate-type business strategy; Nitchitsu, formed around Nippon Chisso Hiryo Kabushiki Kaisha (Japan Nitrogenous Fertilizer Co., Ltd.), Japan's biggest ammonium sulfate producer; Mori, formed around Showa Hiryo Kabushiki Kaisha (Showa Fertilizer Co., Ltd.), Japan's second biggest producer of ammonium sulfate and Nippon Denki Kogyo Kabushiki Kaisha (Japan Electrical Manufacturing Co., Ltd.), the pioneer aluminum maker in Japan; Nisso, formed on the basis of the soda and metallurgical industries; and Riken, formed through the commercialization of the research findings of the Rikagaku Kenkyujo (Institute of Physical and Chemical Research).

In Part II Udagawa analyzes the general history of the new zaibatsu from the standpoint of the industrial pioneering activity of their founders, their structure and characteristics, and their downfall and reorganization under the wartime system. He thereby seeks to clarify the overall picture of the new zaibatsu. Udagawa maintains that the founders were motivated by "business nationalism," a desire to render ser- 
vice to the nation by developing new industries, as well as their own pioneering entrepreneurial spirits, in that they wanted to be the first to develop those industries. Concerning the structure and characteristics of the new zaibatsu, he writes that they were the driving force behind the development of the heavy industries in the prewar Japanese economy, and in many cases they developed a business strategy of aggressively buying out existing companies while actively pushing vertical integration and product diversification. Furthermore, he stresses that in raising the money to support this kind of business strategy the new zaibatsu, in contrast to the old, which eschewed raising funds from outside of the group, actively solicited external capital through stocks, bonds, loans, and the like. As for their wartime fate, Udagawa points out that the new zaibatsu, which had achieved rapid growth by concentrating on fields in which they did not compete with the old combines, were compelled to center their activities on munitions-related industries, having advanced into those areas with the shift to a wartime economy. The advance into munitions-related industries made for inevitable competition with the old zaibatsu, which were developing similar wartime countermeasures. However, Udagawa argues, although the new zaibatsu had no choice but to move into those fields, they were unable to make the transition smoothly and ultimately were overwhelmed by the old combines with their superior coordinating ability.

This book is extremely useful for gaining an overview of the new zaibatsu and for understanding their characteristics. I doubt that any student of the subject other than the author could have produced such a work. This makes Udagawa's achievement all the more praiseworthy.

I would like to conclude with some thoughts concerning the notion of "zaibatsu." The most basic characteristic of Japanese zaibatsu ("zaibatsu" as a scholarly term being restricted to prewar enterprise groups) was that the owner families had exclusive possession of the shares of subsidiary enterprises. Equity participation in the zaibatsu was closed. As a natural result of this, the zaibatsu were averse to raising capital from outside the group through the sale of their stock. Accordingly, the closed nature of stock ownership has become a main pillar of the zaibatsu concept. By contrast, the new zaibatsu offered their shares for public subscription, and one cannot say that equity participation in them was closed. As a natural consequence, moreover, they were positive about raising capital through the sale of stock. Thus, insofar as one's premise is the concept of zaibatsu that has taken root 
in Japanese academic circles, it should be impossible to classify as "zaibatsu" the enterprise groups known as "new zaibatsu." In fact, I have already pointed out this problem on another occasion. Udagawa, while introducing my viewpoint, avoids addressing head-on the issue I have raised. No doubt he had his reasons for sidestepping an investigation into the concept of new zaibatsu. Yet, for one who is highly regarded in the field as an authority on the new zaibatsu, Udagawa has the responsibility to treat this issue at the earliest opportunity possible.

The above problem notwithstanding, this book is a monumental effort, summarizing the research that has been carried out on the new zaibatsu thus far. It will undoubtedly be a starting point for all future studies on the subject.

Translated by Steven Ericson Harvard University 